https://doi.org/10.37208/tgn27112

\section{The brown lacewing Hemerobius atrifrons (Neuroptera: Hemerobiidae) in Glasgow Botanic Gardens, Scotland}

\author{
R.B. Weddle \\ 89 Novar Drive, Glasgow G12 9SS \\ E-mail: richard@canto.plus.com
}

Two specimens of the brown lacewing Hemerobius atrifrons McLachlan 1868 were found in the moth trap at Glasgow Botanic Gardens on 4th October 2016. The species is described as "widespread but local in England, Wales and Scotland, strictly associated with larch trees Larix decidua" (Plant, 2016).

This is the first record for Glasgow, and apparently one of rather few lowland records in Scotland. There is a single specimen of Larix decidua in the Botanic Gardens some $100 \mathrm{~m}$ from the site of the moth trap.

The only other modern Scottish lowland record was made by E.G. Hancock in 1987 at Cander Moss near Stonehouse in South Lanarkshire (NBN, 2018). Historical records from the "Clyde" area were: at Cadder Wilderness SSSI in East Dunbartonshire, just over the Glasgow boundary beyond Possil Marsh in 1880; and at Bridge of Weir (Renfrewshire) in 1884; these were found by J.J.F.X. King (1855-1933) in the early part of his entomological career, and the specimens form part of the King collection at the Hunterian Museum, University of Glasgow. The remaining Scottish specimens of $H$. atrifrons in King's vast collection are from north of the highland line. Similarly, specimens and literature references at the National Museum Collections Centre (NMCC) in Edinburgh are all from upland areas.

The "strict" association with larch (Plant, 2016), conflicts with reports in other sources, which mention Scots pine (Pinus sylvestris) (Elton, 1966), and "other conifers" (McEwen et al., 2001) as alternative hosts.

It seems possible that the relative lack of lowland records of this species in Scotland is partly a reflection of recorder effort, as the U.K. distribution map for the species (NBN, 2018) shows verified records in such areas as north Kent and East Anglia (the highest point in East Anglia is Beacon Hill at 103 m (Wikipedia, 2018)). However, Séméria \& Berland (1988) describe $H$. atrifrons as a species of mountainous regions, chiefly found at altitudes of 1,000 - 1,800 m, but concur with Plant (2016) that it is quite localised. This view may therefore have influenced recent Scottish recorders' expectations.

In addition, $H$. atrifrons is a comparatively small insect, and, along with other members of the Hemerobiidae, could often have been left unidentified before the publication of the AIDGAP key. However, in the field this species is potentially one of the more easily identified hemerobiids in view of its combination of darkened patches on the forewings, a fully glossy-black face, and a thorax with a median yellow stripe (though it is generally advisable also to check details of the wing venation under magnification). It seems quite likely that focused recording in lowland areas, such as the larger Glasgow parks, may generate further records.

The lowland records mentioned above, along with King's upland records, have been added to the Glasgow Museums Biological Record Centre database (which previously held no records of this species).

I am grateful to Jeanne Robinson for records from the King collection, to Ashleigh Whiffin for facilitating access to the NMCC collections and SIRI (Scottish Insect Records Index), to Richard Sutcliffe for information about specimens in the Glasgow Museums collections, and to Craig Macadam (Buglife) for useful comments on distribution.

\section{REFERENCES}

Elton, C.S. (1966). The Pattern of Animal Communities. Springer, Netherlands.

McEwen, P.K., New, T.R. \& Whittington, A.E. (Editors) (2001). Lacewings in the Crop Environment. Cambridge University Press, Cambridge. https://doi.org/10.1017/CBO9780511666117

NBN (2018)

https://species.nbnatlas.org/search/?q=Hemerobius +atrifrons

Plant, C.W. (2016). A Key to the Adults of British Lacewings and their Allies. Field Studies Council AIDGAP Guides. Vol. 245. Field Studies Council, Shrewsbury.

Séméria, Y. \& Berland, L. (1988). Atlas des Névroptères de France et d'Europe. Société Nouvelle des Éditions Boubée, Paris.

Wikipedia (2018). https://en.wikipedia.org/wiki/Beacon_Hill,_Norfolk 